\title{
Commentary
}

\section{Human Trafficking and the UK Modern Slavery Bill}

\author{
Gary Craig ${ }^{1,2}$ \\ ${ }^{1}$ Durham University, County Durham DH1, UK; E-Mail: Gary.craig@durham.ac.uk \\ ${ }^{2}$ Wilberforce Institute for the Study of Slavery and Emancipation, Yorkshire HU6 7RX, University of Hull, UK; \\ E-Mail: g.craig@hull.ac.uk
}

Submitted: 10 December 2014 | Accepted: 19 December 2014 | Published: 23 February 2015

\begin{abstract}
This article provides a commentary on growing awareness of human trafficking to and within the United Kingdom and government responses to it.
\end{abstract}

\section{Keywords}

forced labour; modern slavery; trafficking

\section{Issue}

This commentary is part of the special issue "Perspectives on Human Trafficking and Modern Forms of Slavery", edited by Siddharth Kara (Harvard Kennedy School of Government, USA).

(C) 2015 by the author; licensee Cogitatio (Lisbon, Portugal). This article is licensed under a Creative Commons Attribution 4.0 International License (CC BY).

Two hundred years after William Wilberforce led the UK parliamentary campaign to abolish the Transatlantic Slave Trade, ${ }^{1}$ British parliamentarians have woken up to the fact that slavery still existed, not just, as many thought, on the other side of the world in exploitative or poorly regulated labour markets, or in autocratic dictatorships, but on their own doorstep. Disbelief in the existence of modern slavery, in all its forms, was widely shared: as Archbishop Desmond Tutu, no stranger to exploitation, put it in 1999, "Slavery...I didn't know about all these forms that existed. I think it's largely because we aren't expecting it. It is hidden. Generally people would not believe that it is possible under modern conditions. They would say 'No I think you are making it all up', because it's just too incredible" (Tutu, 1999, as cited in Craig, 2007).

The British government was thus initially reluctant

\footnotetext{
${ }^{1}$ It is probably worth noting that, in line with many other claims made by the UK government to be world-leading, the claim that this was an innovative initiative is not true. Denmark had abolished the slave trade in its colonies in the late $18^{\text {th }}$ century, several decades before the UK. The UK Act was however significant because the UK had industrialised the slave trade, making it larger, more efficient and more profitable-for a while - than it otherwise might have been.
}

to endorse all aspects of what has come to be known as the Palermo Protocol, the legal instrument established by the United Nations in 2000 to "prevent, suppress and punish trafficking in persons, especially women and children" (Palermo Protocol, 2000), supplementing the United Nations Convention against Transnational Organised Crime, and followed in 2005 by the Council of Europe Convention on Trafficking in Human Beings. Questions in the UK parliament revealed considerable ignorance of the scope and scale of trafficking; estimates of those involved were very vague and, as it later turned out, hopelessly undercounted the actual numbers involved.

As evidence grew (supported by growing awareness of the related issue of forced labour-for example, the death of 23 Chinese cockle pickers working for a criminal gangmaster, who drowned off the English coast in 2004-and more general labour exploitation), the UK began to move on the issue establishing, in 2007, a new organisation, the UK Human Trafficking Centre (UKHTC), staffed largely by serving police officers, to monitor and collect data, and report to government on the extent of human trafficking. By 2013, the scale of human trafficking emerged more clearly. The UKHTC, now part of the umbrella National Crime Agency, re- 
ceived almost 3000 referrals that year, from so-called First Responders, ${ }^{2}$ of alleged trafficking victims to its National Referral Mechanism (NRM), the official "entry point" for victims seeking "rescue" and rehabilitation. By then, it also became clear that human trafficking, whether for sexual or labour exploitation, was the tip of a much larger modern slavery iceberg. The Joseph Rowntree Foundation, a charitable foundation sponsoring research into poverty and disadvantage published a report in 2007 into the scope of modern slavery in the UK (Craig, Wilkinson, Gaus, Mcquade, \& Skrivankova, 2007), following this with a large research programme into forced labour (see Joseph Rowntree Foundation (n.d.), for example, Geddes, Craig, \& Scott (2013)). By 2014, it had become clear that both the scale of modern slavery was much larger than had been presumed, and that its scope was also much wider than had been understood, with new forms of slavery practice becoming much more common within the UK. These included the imprisonment of young (often Vietnamese) men by Chinese gangs to manage cannabis "farms", the severe physical and sometimes sexual exploitation of domestic workers by wealthy businessmen/women and diplomats, forced begging and theft by young children trafficked or smuggled into the UK for this purpose and the suggestion, although as yet unsubstantiated, that some people had been trafficked into the UK for the purposes of organ harvesting. ${ }^{3}$

The growing clamour around issues of modern slavery, focused initially on the issue of trafficking for sexual purposes in particular, where a number of prominent NGOs had been active in lobbying government, alongside growing pressure from groups of MPs, finally led to the government agreeing to publish a draft Modern Slavery Bill, which appeared in December 2013. This Bill (HoC, 2013) was very weak and led to substantial criticism from virtually every side, notwithstanding the claim by government that it was intended to be world-leading in the fight against modern slavery. The draft Bill went through an unusual process before reappearing in a final form before Parliament in June 2014, being subject to examination by a Joint Select Committee ${ }^{4}$ and by a separate All-Party Group of MPs, each of which was highly critical of much in the Bill and much that should have been but wasn't. The Bill was

\footnotetext{
2 First Responders are a range of organisations which have the responsibility for referring alleged victims of trafficking into the NRM: these include immigration authorities, local council children's services departments, police forces, some Nongovernmental organisations and other criminal justice agencies ${ }^{3}$ Organs such as livers and kidneys are removed under compulsion or duress of some kind (for example to settle cases of debt bondage), often in dangerous contexts, for sale to wealthy people requiring transplants.

${ }^{4}$ Specifically-nominated group of representatives from both the Commons (the Lower House) and the Lords (the Upper House)
}

also subjected to pre-legislative scrutiny (a more technical legalistic process) and examined by other interests within Parliament (such as the Joint Committee on Human Rights) for any implications for their own work. At the same time, many individuals, organisations, NGOs, researchers and others, took the opportunity to promote their own critiques. By the time the government's final Bill was published, it had thus been very thoroughly scrutinised, the government's claim that it was world-leading looking fragile indeed. ${ }^{5}$

Before a Bill becomes an Act of parliament, it passes through a series of processes: in a nutshell, these involve detailed debate in a special Bill Committee, in which existing clauses are fought over and new ones (possibly) added (Committee stage); an amended Bill is then presented to the Commons (Report stage) when the whole House has the chance to debate it, clause by clause; passage then to the House of Lords where a very detailed and possibly elongated debate takes place through a similar process; and return to the House of Commons in an amended form when final debates take place and, normally, the government has its way, in the process often nullifying many changes which the Lords have made. Given that the government intends the Bill to be enacted by the end of Parliament, this requires it to pass through all its stages essentially by Easter $2015 .^{6}$

Despite growing awareness of the much wider scope of modern slavery, most of the Bill remains focused on the issue of human trafficking. Much of the early work of the Commons Committee debating the Bill focused on establishing the precise wording needed to encompass all the possible offences which might be involved, and how children in particular might be protected by its provisions. ${ }^{7}$ One key argument has been

\footnotetext{
${ }^{5}$ There has been considerable debate as to why, in the last year of a five year parliament, the Home Secretary Theresa May, should bother to promote a Bill of this kind which was unlikely to be a large votewinner. Most explanations have come to rest around the view that, if the General Election is unkind to the Conservative Party and the current leader David Cameron is obliged to resign the leadership, it would not harm May's ambitions to be party leader if she were associated with legislation which would distance her from the epithet of "nasty party" often attached to the Conservatives. Her behaviour during the passage of the Bill suggests that she personally has had some difficulty in maintaining that distance.

${ }^{6}$ By the time of reading this, we shall know whether this was the case and in what form the Bill finally reached the statute book. Much concern regarding this timetable is centered on the Lords where it is feared that everyone will have a viewperhaps at great length-and that time will be so pressured by the point at which the Bill goes back to the Commons, that serious issues may be lost or not debated.

7 This is important as the UK judiciary remains largely very illinformed about the nature of modern slavery and has often either failed to recognise the seriousness of offences or regarded victims of trafficking or forced labour as criminals. The gov-
} 
about what form the precise protection for children might take with one suggested scheme, involving children being provided by the state with Advocates, to defend the best interests of the child, being piloted by an NGO. ${ }^{8}$ Whilst the issue of trafficking remains very central to the Bill, this has essentially focused almost entirely on trafficking for sexual exploitation of adults and children (those defined by the UK to be under 18).

The issue of trafficking for labour exploitation, and of forced labour (which can occur whether or not trafficking is involved) is receiving far less attention. Although forced labour was made a freestanding criminal offence in $2009,{ }^{9}$ thus technically detaching it from the issue of trafficking, the number of cases brought before the courts remains very low and in one notable case, Operation Ruby, what was a clear-cut and very wellprepared case of forced labour was thrown out by the judiciary who had, it seemed, a very limited understanding of how forced labour worked, the judge arguing that if people were free to move around, they could not be regarded as being enslaved: this completely failed to understand the nature of psychological or emotional compulsion. At the time of writing, one important victory appears to have been won with the government finally agreeing to include a clause requiring companies to take some responsibility for exploring whether slavery might be found in their supply chains. ${ }^{10}$ Contrarily, the Committee however has failed to respond to demands to protect domestic workers.

ernment is now committed to recognising victims as just that. 8 This is one of several initiatives the government has taken whilst the Bill is still being debated. Another is to create a Modern Slavery Unit within the Home Office; yet another to move departmental responsibility for the Gangmasters' Licensing Authority, which scrutinises businesses for evidence of forced labour, from the agricultural department (DEFRA) to the Home Office; a fourth to review the NRM in light of the scathing critique developed by many organisations (see the reports produced by the Anti-Trafficking Monitoring Group, n.d.); and a fifth, to advertise publicly for the post of Anti-Slavery Commissioner. This role, essentially that of a national rapporteur, was recommended by the Council of Europe to be an independent one but, although the Bill alludes to an Independent Commissioner, it is far from clear that the Commissioner can work free from government interference and, for example, report direct to Parliament. To advertise the post whilst the issue has yet to be debated in Parliament smacks of a government determined to get its own way. The pilot project is being undertaken by Barnados, a leading UK children's charity (n.d.).

${ }^{9}$ In a clause in the Coroners and Justice Act 2009 (TSO, 2009).

${ }^{10}$ See the report by J. Allain and colleagues on this issue, available through the JRF website, see footnote 5 (Allain et al., 2013). Perhaps surprisingly, some big businesses have supported further regulation, arguing that unscrupulous companies, using forced labour, would be able to price their goods lower, thus taking a greater market share from the "better" companies.
There has also been substantial pressure to extend the remit (and thus the resources) of the Gangmasters Licensing Authority from its current narrow focus on three industrial sectors to many more (or even the whole of the labour market), which would probably require it to move its departmental home again. At present the GLA is only able effectively to investigate a small fraction of possible forced labour cases.

The outcome of these debates remains to be seen and lobbying will remain intense right up to the day of enactment. At present, whilst it seems that claims for the UK to be world-leading in its legislation may be somewhat overblown (not least because it has been taking advice from other countries on the form of various proposals), there is no doubt that many other states are watching the Bill's progress with interest and hopefully will learn from it. Once enacted, it will provide many improvements and provide a focus for further debate and improvement, though there is a huge task to turn law and policy into practice. There is little doubt however that it will be considerably less than 200 years before another Act comes to be placed on the statute book.

\section{Conflict of Interests}

The author declares no conflict of interests.

\section{References}

Allain, J., Crane, A., Le Baron, G., \& Behbahani, L. (2013). Forced labour's business models and supply chains. York: Joseph Rowntree Foundation.

Anti-Trafficking Monitoring Group. (n.d.). What we do. Retrieved from: www.antislavery.org/atmg

Barnados. (n.d.). Retrieved from: www.barnados.org.uk

Craig, G. (2007). Speech at launch of UK Human Trafficking Foundation, Leeds, UK, 14 November 2007.

Craig, G., Wilkinson, M., Gaus, A., Mcquade, A., \& Skrivankova, K. (2007). Modern slavery in the UK. York: Joseph Rowntree Foundation.

Geddes, A., Craig, G., \& Scott, S. (2013). Forced labour in the UK. York: Joseph Rowntree Foundation.

HoC. (2013). Draft modern slavery bill. Presented to Parliament, Cm 8770, December 162013.

Joseph Rowntree Foundation (n.d.). Forced labour. Retrieved from www.jrf.org.uk/search/site/forced\%20 labour

Palermo Protocol. (2000). Protocol to prevent, suppress and punish trafficking in persons, especially women and children, supplementing the United Nations convention against transnational organized crime. New York: United Nations.

TSO. (2009). Coroners and Justice Act (c.25). London: The Stationery Office. 


\section{About the Author}

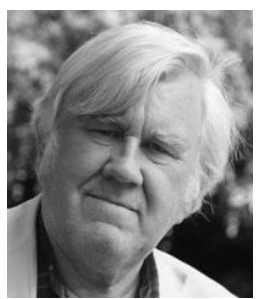

\section{Gary Craig}

Gary Craig is Professor of Social Justice at Durham University and Emeritus Professor of Social Justice at the Wilberforce Institute for the study of Slavery and Emancipation, University of Hull. His major researches at present focus on different aspects of modern slavery such as forced labour and human trafficking although he researches more widely in the fields of "race" and ethnicity. He currently coordinates the forced labour monitoring group within the UK: www.flmg.org 